\title{
Priming Effects for the Unexpected Stimulus in Inattentional
}

\section{Blindness}

\author{
Merve Çakar' ${ }^{1}$, Simay İkier ${ }^{2}$
}

Çakar, M., \& İkier, S. (2021). Priming effects for the unexpected stimulus in inattentional blindness. Nesne, 9(19), 19-28. DOI: 10.7816/nesne-09-19-02

\begin{abstract}
Keywords $\quad$ Studies on inattentional blindness demonstrate that a stimulus that unexpectedly appears in the visual environment inattentional may be undetected when attention is engaged in a task. The stimulus can still be processed and remembered at the blindness, priming, perceptual and semantic level. The question of whether this is still the case when there are items to be ignored in the consciousness, visual environment remains. In the present study investigating this question, participants attended to furniture perceptual pictures while they ignored other pictures. In the inattention trial, an unexpected word appeared in the middle of the processing, circular display. Participants blind to the word were compared to ones who were not exposed to the word. In semantic processing Experiment 1, participants were more likely to complete a word fragment with this word than the ones who were not exposed to the word. In Experiment 2, participants were more likely to choose the picture of this word than the ones who were not exposed to the word. These studies show that the undetected unexpected stimulus is processed at the perceptual and semantic level and produces priming effects on a subsequent task. Findings were discussed with regards to the possible memory correlates of undetected visual information and levels of consciousness.
\end{abstract}

Anahtar kelimeler dikkatsizlik körlüğü, hazır olma, bilinç, algisal işleme, anlamsal işleme

\section{Dikkatsizlik Körlüğündeki Beklenmeyen Uyaran için Hazır Olma Etkileri}

Öz

Dikkatsizlik körlüğü üzerine yapılmış olan araştırmalar, dikkat bir göreve odaklandığında görsel çevremizde beklenmedik bir şekilde beliren uyaranların farkedilemeyebileceğini göstermiştir. Bu uyaran yine de algısal ve anlamsal düzeyde işlenir ve hatırlanabilir. Bu durumun görsel çevrede dikkatimizi yöneltmememiz gereken uyaranların olduğu durumda da geçerli olup olmadığı sorusu henüz tam olarak yanıtlanamamıştır. Bu soruyu inceleyen iki deneyde, katılımcılar eşya resimlerine dikkatlerini odaklamış ve diğer resimlere dikkatlerini yönlendirmemişlerdir. Dikkatsizlik körlüğü aşamasında beklenmeyen bir sözcük, dairesel sunumun ortasında belirmiştir. Bu sözcüğ̈̈ görmediğini belirten katılımcıların verisi, bu sözcüğe hiç maruz kalmamış katılımcıların verisi ile karşılaştırılmıştır. Deney 1'de katılımcıların bir sözcük parçasını bu sözcükle tamamlama olasılıkları sözcüğe hiç maruz kalmamış katılımcılardan daha fazladır. Deney 2'de ise, katılımcıların bu sözcüğ̈̈n resmini seçme olasılıkları sözcüğe hiç maruz kalmamış katılımcılardan daha fazladır. Bu çalışmalar farkedilmeyen beklenmeyen uyaranın algısal ve anlamsal düzeyde işlendiğini ve izleyen görevde bir hazır olma etkisi (priming) yarattı̆ını ortaya koymuştur. Bulgular, farkedilmeyen uyaranın bellek ile muhtemel bağları ve bilicin düzeyleri çerçevesinde tartışılmıştır.

Article History

Arrived: August 9, 2020

Revised: December 30, 2020

Accepted: February 24, 2021

DOI: 10.7816/nesne-09-19-02

\footnotetext{
${ }^{1}$ Specialized Psychologist, Yeditepe University, Cognitive Science Program, e-mail: merveyorur(at)hotmail.com, ORCID: 0000-0001-6931-8111

${ }^{2}$ Assoc. Prof., Bahçeşehir University, Department of Psychology, e-mail: simay.ikier(at)eas.bau.edu.tr, ORCID: 0000-0003-3810-0958
} 
We cannot pay attention to every visual stimulus in our environment. This would be exhausting and would prevent us from concentrating on a task. Thus, attention will filter some of the visual information, while we focus on a task. Then again, we would find it difficult to believe that we may not see a gorilla that appears unexpectedly in a basketball field. This is in fact an indication of our blindness to the extent of our blindness for unexpected stimuli in our visual environment. Previous studies showed that some participants failed to notice a person in a gorilla suit walking across a basketball field (Simons \& Chabris, 1999) and three people fighting at the side of the road they are jogging on (Chabris, Weinberger, Fontaine \& Simons, 2011). Expert radiologists failed to notice the picture of a gorilla 48 times larger than the nodules when they were engaged in the task of detecting nodules on a lung film (Drew, Võ, \& Wolfe, 2013). The reason for the failure to notice such obvious stimuli in all these studies was the fact that the participants' attention was directed to another task. This failure to notice the unexpected stimulus (US) when attention is engaged in a task is termed Inattentional Blindness (IB; Mack \& Rock, 1998).

One question about IB is related to whether and to what extent the undetected US is processed. A study showed brain activations for the undetected US before the onset of conscious awareness (Iamshchinina, \& Kuvaldina, 2014). Other studies showed eye fixations on or at the location of the US, for inattentionally blind participants (Drew et al., 2013; Memmert, 2006). While these studies indicate that US may be processed, more direct evidence of a memory trace for the US came from studies in which priming effects for the undetected US were investigated. Priming effects are revealed in indirect tests of memory in which the participant is not aware of being in a memory test (Schacter, 1989). Indirect memory tests showed that US is processed and the non-conscious information acquired about the US can affect responses on a subsequent task.

In the initial studies, Mack and Rock (1998) used a static IB paradigm in which participants were asked to judge which arm of a cross is longer. Eventually, a US word appeared in one of the quadrants of the cross. In a subsequent word stem completion task, participants who were blind to the US were more likely to complete the stem with the US than the ones who were not exposed to it. In another experiment involving a similar paradigm, the subsequent task was to choose one of the presented pictures and participants who were blind to the US word were more likely to choose the picture of the US than the ones who were not exposed to it. These priming effects showed that the undetected US can even be processed at the semantic level. These findings can be considered as evidence of perceptual and conceptual priming for the US and support the Late Selection Theory of attention which claims that attentional filtering takes place after semantic analysis (Deutsch \& Deutsch 1963).

Simons and Chabris (1999) criticized Mack and Rock's (1998) findings for the absence of distractors to be inhibited in the paradigm. They claimed that in paradigms in which some items are ignored, the US can be ignored and result in the absence of a memory trace. In line with this argument, a forced-choice task for the identification of the US had failed to find an implicit memory trace in a selective looking task (Neisser \& Rooney 1982, as cited in Becklen \& Cervone 1983). More recent studies continued to show mixed results with regards to whether the undetected US can be processed at the perceptual and semantic level when there are distractors to be ignored in the IB paradigm. While some of these studies used indirect tests of memory, once more investigating priming effects, others used direct tests of memory such as recognition, in which the participant is aware of the retrieval of the acquired information (Roediger \& McDermott, 1993). Rees, Russell, Frith and Driver (1999) used a paradigm in which words were superimposed on pictures and showed that ignored words in an IB paradigm were produced only at chance level as responses in a surprise 
recognition test. These results implied that the unattended US is not processed at the semantic level, further supported by the absence of differences in brain activations for meaningful and non-meaningful items. Butler and Klein (2009) used a similar paradigm and similarly failed to find evidence of a memory trace in a recognition test for unattended words that were superimposed on attended pictures. Surprisingly, they also did not find priming effects for the unattended words in a category association test in which participants could generate the unattended words as exemplars to a given category. Category generation is an indirect memory test that requires conceptual processing of the information. Participants can only generate the exposed items at a greater than baseline level if they have access to the item's meaning. Butler and Klein (2009) found priming effects for ignored stimuli in a perceptual identification task that only requires the perceptual processing of the unattended stimulus. These results indicate that the unattended words were processed at the perceptual, but not at the semantic level. It should be noted however the paradigm in the Rees et al. (1999) and Butler and Klein (2009) study required participants to intentionally attend to some of the stimuli and ignore others. The ignored stimuli did not appear unexpectedly and thus ignoring was not automatic like in other IB paradigms (e.g., Koivisto \& Revonsuo, 2007). Schnuerch, Kreitz, Gibbons and Memmert (2016) showed that in a task in which participants categorized numerals based on their values, US numerals at unattended locations that were undetected by the participant affected the speed of categorization. Categorization was faster if the US was congruent with the numeral in the target task and slower if it was incongruent. These findings indicate that the US is processed at the semantic level, as evident in increased efficiency. However, it should be noted that the findings do not show whether the processed information can affect the verbal response or the choices of a participant in a subsequent task. In this sense, the results are not totally compatible with the findings of Mack and Rock (1998) in which the undetected US increases the likelihood that the US is verbally generated or chosen as a response.

Koivisto and Revonsuo (2007) conducted a study in which the attended pictures in the primary task were either semantically congruent (e.g., animal pictures) or incongruent (e.g., furniture pictures) with the US (e.g., animal word). This paradigm also involved some unattended pictures in the primary task. Results showed that detection of the US was higher in the congruent condition than the incongruent condition. They claimed that the attentional set that the participants form at the semantic level when they attend to a category of pictures affects whether the US will be detected. In this study, it was the semantic category of the attended stimuli that primed the participants to detect the categorically related US. These findings indicate that the US can be processed at the semantic level, at least when the attentional set aids its detection.

Given the inconsistencies in the literature with regards to methods and outcomes, the present study aims to replicate Mack and Rock (1998) findings in a paradigm with ignored items and show that the processing of the undetected US can produce priming effects at the perceptual and semantic level. In the present study, two experiments were conducted by using a paradigm similar to Koivisto and Revonsuo (2007). While that paradigm primed participants with the stimuli in the primary task to determine their attentional set, the present one primed participants with a US word, while participants attended to some of the stimuli in the primary task and ignored others. Recently, Wood and Simons (2019) aimed to replicate Mack and Rock (1998) stem completion priming findings with a large online sample. The results showed that only three out of 308 inattentionally blind participants completed the stem with the US. They claimed that the reason for the discrepant results may be that the USs they used were rare words. This non-replication further complicates the conclusions. In the present study, in order to have a clearer differentiation, priming for the US was investigated with a single-solution word fragment completion task, which is considered to be a highly perceptual indirect test (Roediger \& Blaxton, 1987). In Experiment 2, a non-verbal picture choice task was used in which priming effects are dependent on the semantic processing of the US word. 


\section{Experiment 1}

In Experiment 1, it was hypothesized that the undetected US can be processed at the perceptual level and that it can lead to priming effects on a subsequent word fragment completion task. Word fragment completion tasks are considered to be highly perceptual tasks (Roediger \& Blaxton, 1987) and thus the perceptual similarity of the target and the fragment can produce priming, without the need for semantic analysis.

\section{Participants}

\section{Method}

Six participants in the experimental group who were unable to state that the word critical word appeared in the middle of the display in the full attention trial in which they did not focus on the primary task and were especially asked to pay attention to whether there is anything new or additional other than the pictures, before the presentation of the display were replaced like in previous studies (Koivisto \& Revonsuo, 2007; Mack \& Rock, 1998). The final sample consisted of 40 participants in the experimental $\left(M_{\text {age }}=19.53\right.$, $S D_{\text {age }}=1.18,20$ females $)$ and 40 participants in the control group $\left(M_{\mathrm{age}}=19.50, S D_{\mathrm{age}}=1.13,24\right.$ females $)$ were tested. All participants were university students.

\section{Materials and Procedure}

Data were collected in 2017. The study was conducted by adhering to the ethical rules and principles of testing human participants. Informed consent was obtained from all participants. Trials were presented on a 15.6-inch monitor. For the experimental group, there were four trials. Each trial was presented for $350 \mathrm{~ms}$, and was preceded by a fixation cross $(1500 \mathrm{~ms})$ and followed by a mask (1000 ms). In Trials 1-3, participants were asked to attend to the furniture pictures and write their names when the mask appeared. The pictures were chosen from Snodgrass and Vanderwart (1980) and had an average size of 2.7 X $2.7 \mathrm{~cm}$. They were presented on a white circle $(12.2 \mathrm{~cm}$ in diameter) superimposed on a black square $(14 \mathrm{X} 14 \mathrm{~cm})$. Each picture was placed $3.7 \mathrm{~cm}$ away from the fixation cross in the middle of the circle. Trial 1 included the pictures of a horse, a bow, a ball and a lamp. Trial 2 included the pictures of a bed, a chair, an elephant and a lion. Trial 3 (inattention) and Trial 4 (full attention) included the pictures of mushroom, a table, a dog and a guitar. In trials 1-4, furniture pictures were the targets (lamp, bed, chair, table and guitar). In Trial 3, which it the inattention trial, the Turkish word for kangaroo, 'KANGURU' $(0.7 \times 3.75 \mathrm{~cm})$ appeared in the middle of the circle instead of the cross as the US and after the display, participants were asked to state whether they noticed anything new or additional, other than the pictures and if they did what and where. Immediately after, the single-solution word fragment for the US was presented and participants were asked to write the first word that came to their mind that completes the fragment correctly (KA__U_U) on a piece of paper. In Trial 4, which is the full attention trial, participants were just asked to attend to whether anything new or additional was presented other than the pictures (Figure 1). The procedure for the control group was exactly the same, except that the US was not presented in Trial 3 and Trial 4 was not applied. All participants were debriefed about the details of the study. 


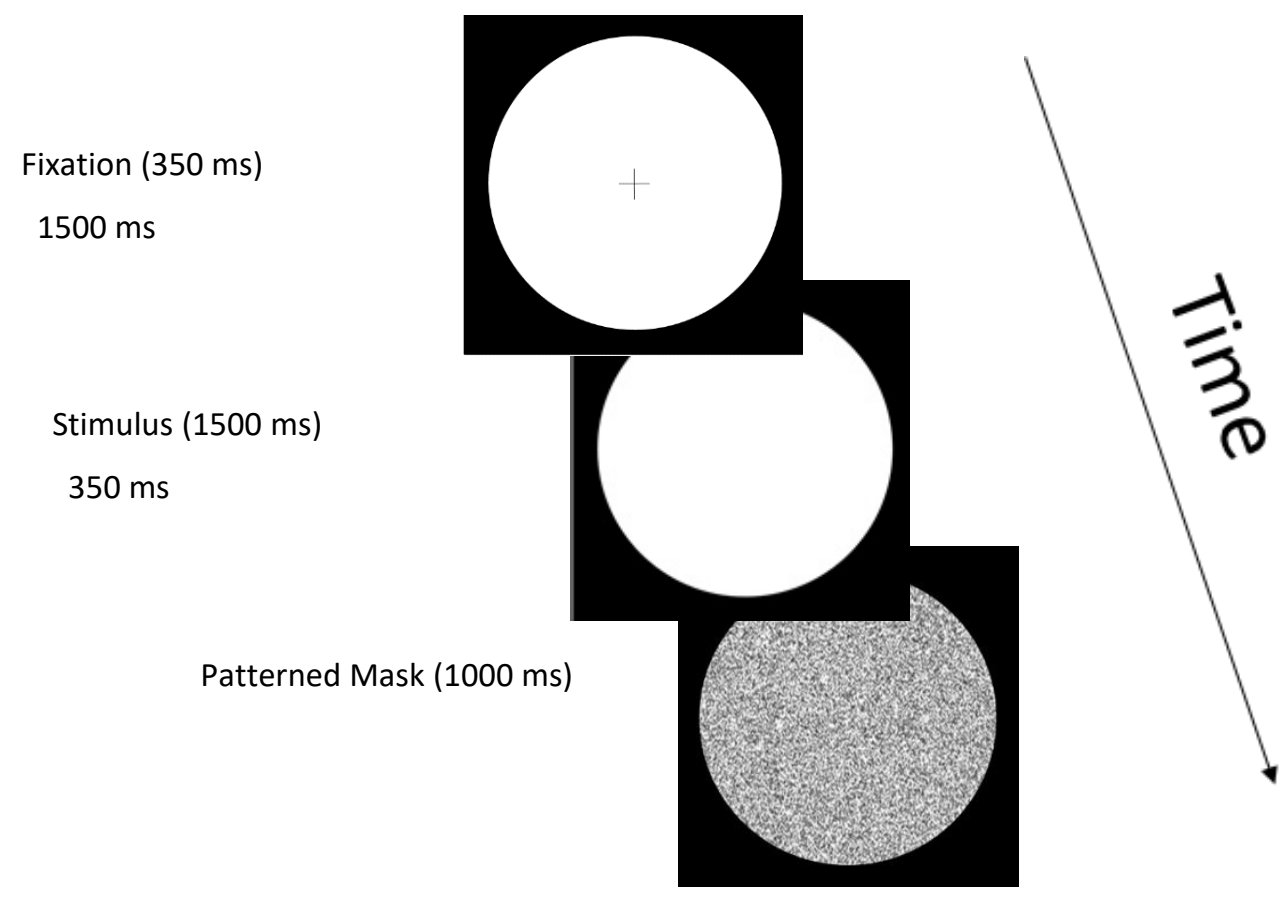

Non-critical Trial

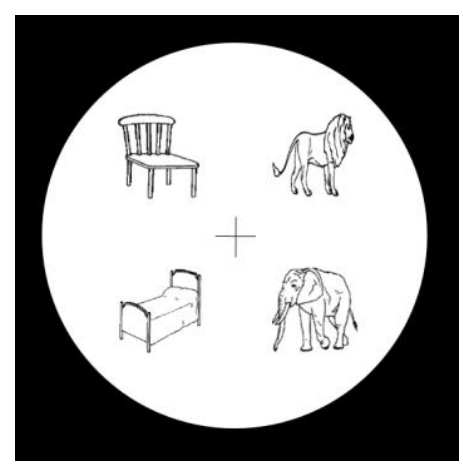

E1- Fragment Completion

AŞAĞIDAKi HARFLERLE BAŞLAYAN AKLINIZA ILK GELEN SÖZCÜĞÜ YAZINIZ

$\mathrm{KA} \mathrm{A}_{-} \mathrm{U}_{-} \mathrm{U}$

Critical Trial

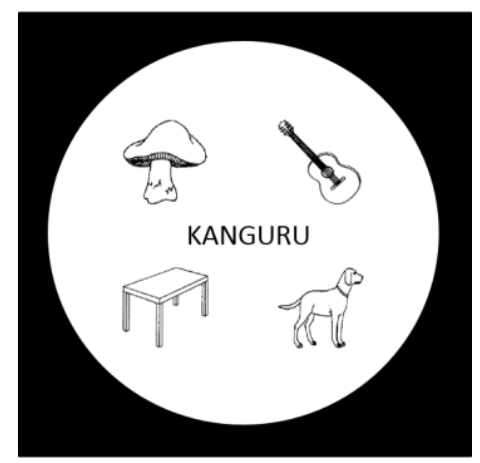

E2-Picture Choice

AȘAĞIDAKI RESIMLERDEN HERHANGI BIRINI SEÇIP NUMARASINI KAĞIDA YAZINIZ

1.

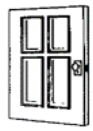

3.

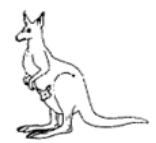

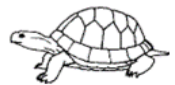

4.

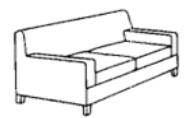

Figure 1. Trials in the procedure 


\section{Results}

Participants were classified as showing IB if they were unable to state that the word KANGURU appeared in the middle of the display, in the inattention trial. All participants who claimed noticing the word KANGURU were able to claim its position correctly, as being in the middle of the display, in both the inattention and full attention trials. These participants were considered to be the ones that did not show IB. Twenty (50\%) of the participants in the experimental group showed IB. Among those, 12 of them (60\%) completed the fragment with the US. In the control group, only 12 participants $(30 \%)$ completed the fragment with the US. The difference was significant, $X^{2}(1, N=60)=5.00, p<.05, \varphi=.29$. All participants who were not inattentionally blind completed the fragment with the US. In the inattention trial, primary task performance was high, $95 \%$ of the blind participants in the experimental group and $93 \%$ of the participants in the control group detected at least one of the furniture pictures in the primary task.

\section{Discussion}

Inattentionally blind participants completed the fragment with the US significantly more than the control group. The results replicated Mack and Rock (1998) stem completion results with a fragment completion task and showed that the undetected US is processed at the perceptual level and can produce priming effects in a subsequent task. Results indicate that there is an implicit memory trace for the undetected US in IB even in paradigms with items to be ignored.

\section{Experiment 2}

Experiment 1 showed that the undetected US can be processed and produce priming effects at the perceptual level. Experiment 2 is conducted to investigate whether the undetected US can be processed and lead to priming effects at the semantic level. It was hypothesized that the undetected US can be processed at the semantic level, and produce priming effects on a task in which the US is not perceptually similar to the target response.

\section{Participants}

\section{Method}

Once more, ten participants, who were unable to state that the word KANGURU appeared in the middle of the display in the full attention trial, despite that in this trial they did not focus on the primary task and were especially asked to pay attention to whether there is anything new or additional other than the pictures, before the presentation of the display, were replaced. The final sample included 40 participants in the experimental $\left(M_{\mathrm{age}}=19.13, S D_{\mathrm{age}}=1.04,16\right.$ females $)$ and 40 participants in the control group $\left(M_{\mathrm{age}}=\right.$ $19.62, S D_{\text {age }}=1.56,24$ females $)$. None of the participants had participated in Experiment 1 and all of them were university students.

\section{Materials and Procedure}

Data were collected in 2017. The study was conducted by adhering to the ethical rules and principles of testing human participants. Informed consent was obtained from all participants. The materials and procedure were the same as Experiment 1, except that, instead of the fragment completion task, a picture choice task was presented. The pictures were a door, a turtle, a kangaroo (target) and an armchair. 
Participants were asked to choose one of the four pictures and write the number of the picture they chose on a piece of paper. All participants were debriefed.

\section{Results}

Similar to Experiment 1, participants were classified as showing IB if they did not state that they saw the unexpected word in the middle of the display, in the inattention trial. All participants who noticed the unexpected word were able to claim its position correctly, as being in the middle of the display. In the experimental group, 32 participants (80\%) showed IB. Of those participants, 12 of them $(37.5 \%)$ chose the picture of the kangaroo. In the control group, only 5 participants $(12.5 \%)$ chose the picture of the kangaroo. The difference between the groups was significant, $X^{2}(1, N=72)=6.20, p<.05, \varphi=.29$. All of the participants who were not blind selected the kangaroo picture. In Trial 3, primary task performance was high, $97 \%$ of the blind participants in the experimental group and $95 \%$ of the participants in the control group detected at least one of the furniture pictures in the primary task 2 .

\section{Discussion}

As hypothesized, participants who were blind to the US selected the picture of the US significantly more than the control group. These findings are consistent with the findings of Mack and Rock (1998). The present results indicate that perceptual similarity between the US and the item in the indirect test is not necessary to obtain priming effects. They also indicate that the US is processed at the semantic level, despite that it is not consciously detected and despite that there are items to be ignored in the paradigm.

\section{General Discussion}

The present study investigated the question of whether the undetected US in IB is processed at the perceptual and semantic level and whether it can reveal priming effects on a subsequent task. Mack and Rock (1998) engaged participants in a primary task while in the inattention trial an unexpected word appeared. Participants who were blind to the US were more likely to complete the word stem with the US than the ones who were not exposed to it. In another indirect test, pictures of objects whose first letters of their names were common with the US word were presented to the participants. Once more, participants who were blind to the US were more likely to choose the picture of the US than the ones who were not exposed to it. Mack and Rock's (1998) stem completion results were not replicated by using a large online sample (Wood \& Simons, 2019), possibly due to using multiple-solution word stems as cues for rare US words. Mack and Rock (1998) results also left open the question of whether priming effects for the undetected US can still be obtained in a paradigm in which there are items to be ignored. As outlined in the introduction, the studies investigating this question revealed mixed results, further complicated by the use of various paradigms and measurements.

The present study replicated Mack and Rock (1998) findings in a paradigm with ignored items and showed that the undetected US in an IB paradigm is processed at the perceptual and semantic level and can affect the subsequent responses of the participant. In Experiment 1, participants who were blind to the target word were more likely to complete the word fragment with the target than the ones who were not exposed to the target. In this experiment, the response cue was perceptually similar to the US, and thus the findings suggest that processing of the US at the perceptual level results in priming. Experiment 2 showed that despite the semantic incongruency between the attended stimuli (furniture category) and the US (animal 
word), the US is processed at the semantic level and reveals priming effects. Although the physical form of the US (word) was different from the stimuli in the response choices (pictures), priming was still obtained. While Koivisto and Revonsuo (2007) showed that participants were more likely to notice the US that was in the same semantic category as the attended stimuli, the present results showed that the undetected US itself can produce priming effects. The results are consistent with findings showing that semantic processing of a non-target stimulus can occur without conscious access (Naccache \& Dehaene, 2001) and that it can affect the responses on a related task, by creating an ease of processing (Schnuerch et al., 2016).

The present results also have some implications with regards to the types of processing taking place at different levels of consciousness. Block (2011) separates consciousness into two: Phenomenal Consciousness (PC) and Access Consciousness (AC). PC is related to subjective experience. For PC, there is no need for attention or report while for AC, attention is necessary and there is a verbal report. Based on this taxonomy, Block (2011) used the term inattentional inaccessibility instead of blindness. According to inattentional inaccessibility view, participants phenomenally experience the US, however, the lack of conceptualization of the US prevents it from reaching AC and to be interpreted as new or different.

Event-related potential studies also showed that PC is not dependent on attention (Koivisto, Revonsuo, \& Salminen, 2005). Activations related with visual awareness were observed in occitotemporal regions between 100-200 ms after the onset of the visual stimulus, before attention started to play a role at 200 ms. Similarly, Lamme (2004) claimed that even $120 \mathrm{~ms}$ after the onset of a visual stimulus, phenomenal experience is not available to awareness and does not result in a verbal report, similar to what happens in IB. Only $200 \mathrm{~ms}$ after the onset of the stimulus, with feedback from fronto-parietal areas, attention is engaged, and at this stage, the stimulus is accessed and can result in a verbal report.

The present results are consistent with the claims of Block (2011) and Lamme (2004). PC has a relation to iconic memory (IM), which can only keep information for a very brief amount of time, and it has a rich capacity, however the capacity of $\mathrm{AC}$, which is related to working memory (WM) is limited. We have more information than we can report. Information in AC is reportable, however, attention is necessary to activate the information in WM. The undetected US in IB is not attended, so it cannot be activated in WM. Thus, it cannot be reported because visual experience of the stimulus is short-lived. However, even though it is unattended, it can be processed at the phenomenal level, without report (Lamme, 2004). Similarly, Simons (2000) differentiated between explicit versus implicit attentional capture. When a stimulus captures attention explicitly, it can be reported. However, focusing on verbal report underestimates the possibility that the stimulus may have captured attention implicitly and that it can affect participant's subsequent performance.

Recent studies showed that there is a form of visual memory between IM and WM, Fragile Visual Short-term Memory (FVSTM; Pinto, Sligte Shapiro \& Lamme, 2013). FVSTM has larger capacity than WM and stores information up to $4 \mathrm{~s}$, which is longer than the duration of IM. The amount of information in WM decreases without attention, but information stored in FVSTM is independent of attention (Sligte, Wokke, Tesselaar, \& Scholte, 2011). Consistently, in an IB situation, the undetected US may not be in WM, but in FVSTM. This may be the reason why direct tests do not reveal a memory trace for the unattended US (Rees et al., 1999; Butler \& Klein, 2009). The amount of time that passes between the onset of the US and the presentation of the indirect test in the present study implies that the US may be present in FVSTM and that there is an implicit memory trace for it.

One of the shortcomings of the present study is the absence of a separate WM measure. If such a measure was included, it could provide information with regards to why IB is higher in Experiment 2 than in 
Experiment 1 . This difference may be related to different WM capacities of the participants, with low WM participants showing more IB (Hannon \& Richards, 2010). In participants with low WM capacity, the US may not reach later stages of consciousness.

Recent studies showed that IB is evident across different modalities. Murphy and Dalton (2016) showed that IB was high for a tactile US, when the visual primary task was demanding. Future studies can investigate whether the undetected US in a different modality from the stimuli in the primary task can reveal priming effects. Recent findings also show that IB is higher in older adults than in younger adults (e.g., Horwood \& Beanland, 2016). Despite this disadvantage, the question of whether older adults implicitly process the US as well as younger adults remains for future studies.

The present findings imply what we fail to see in our visual environment can affect what we utter and what we choose. The findings also bring up theoretical questions related to the level and type of processing that takes place at a phenomenally conscious level.

\section{References}

Becker, M.W., \& Leinenger, M. (2011). Attentional selection is biased toward mood-congruent stimuli. Emotion, 11(5), 1248-54. doi: 10.1037/a0023524

Becklen, R., \& Cervone, D. (1983). Selective looking and the noticing of unexpected events. Memory \& Cognition, 11(6), 601-608. http://dx.doi.org/10.3758/BF03198284

Block, N. (2011). Perceptual consciousness overflows cognitive access. Trends in Cognitive Sciences, 15(12), 567-575. doi: 10.1016/j.tics.2011.11.001.

Butler, B. C., \& Klein, R. (2009). Inattentional blindness for ignored words: Comparison of explicit and implicit memory tasks. Consciousness and Cognition: An International Journal, 18(3), 811-819. http://dx.doi.org/10.1016/j.concog.2009.02.009

Chabris, C. F., Weinberger, A., Fontaine, M., \& Simons, D. J. (2011). You do not talk about Fight Club if you do not notice Fight Club: Inattentional blindness for a simulated real-world assault. $i$ Perception, 2(2), 150-153.

Deutsch, J. A., \& Deutsch, D. (1963). Attention: Some theoretical considerations. Psychological Review, 70(1), 80.

Drew, T., Võ, M. L.-H., \& Wolfe, J. M. (2013). The invisible gorilla strikes again: Sustained inattentional blindness in expert observers. Psychological Science, 24(9), 1848-1853. http://dx.doi.org/10.1177/0956797613479386

Hannon, E. M., \& Richards, A. (2010). Is Inattentional Blindness Related to Individual Differences in Visual Working Memory Capacity or Executive Control Functioning? Perception, 39(3), 309-319. https://doi.org/10.1068/p6379

Horwood, S., \& Beanland, V. (2016). Inattentional blindness in older adults: Effects of attentional set and tobe-ignored distractors. Attention, Perception \& Psychophysics, 78(3), 818-28.

Iamshchinina, P. A., \& Kuvaldina, M. B. (2014). An ERP Study of Inattentional Blindness Condition. Psychology. Journal of Higher School of Economics, 11(4), 158-174

Koivisto, M., \& Revonsuo, A. (2007). How Meaning Shapes Seeing. Psychological Science, 18(10), 845849. https://doi.org/10.1111/j.1467-9280.2007.01989.x

Koivisto, M., Revonsuo, A., \& Salminen, N., (2005). Independence of visual awareness from attention at early processing stages. NeuroReport, 16(8), 817-821. 
Lamme, V. A. F. (2004). Separate neural definitions of visual consciousness and visual attention: A case for phenomenal awareness. Neural Networks, 17, 861-872.

Mack, A., \& Rock, I. (1998). Inattentional blindness. Cambridge, MA, US: The MIT Press.

Memmert, D. (2006). The effects of eye movements, age, and expertise on inattentional blindness. Consciousness and Cognition, 15(3), 620-627.

Most, S. B., Scholl, B. J., Clifford, E. R., \& Simons, D. J. (2005). What you see is what you set: Sustained inattentional blindness and the capture of awareness. Psychological Review, 112(1), 217-242. http://dx.doi.org/10.1037/0033-295X.112.1.217

Most, S. B., Simons, D. J., Scholl, B. J., Jimenez, R., Clifford, E., \& Chabris, C. F. (2001). How not to be seen: The contribution of similarity and selective ignoring to sustained inattentional blindness. Psychological Science, 12(1), 9-17. http://dx.doi.org/10.1111/1467-9280.00303

Murphy, S., \& Dalton, P. (2016). Out of touch? Visual load induces inattentional numbness. Journal of Experimental Psychology: Human Perception and Performance, 42(6), 761-5.

Naccache, L., \& Dehaene, S. (2001). Unconscious semantic priming extends to novel unseen stimuli. Cognition, 80(3), 215-229. http://dx.doi.org/10.1016/S0010-0277(00)00139-6

Pinto, Y., Sligte, I. G., Shapiro, K. L., \& Lamme, V. A. F. (2013). Fragile visual short-term memory is an object-based and location-specific store. Psychonomic Bulletin \& Review, 20(4), 732-739. http://dx.doi.org/10.3758/s13423-013-0393-4

Rees, G., Russell, C., Frith, C. D., \& Driver, J. (1999). Inattentional blindness versus inattentional amnesia for fixated but ignored words. Science, 286(5449), 2504-2507. http://dx.doi.org/10.1126/science.286.5449.2504

Roediger, H. L. III, \& Blaxton, T. A. (1987). Retrieval modes produce dissociations in memory for surface information. In D. S. Gorfein \& R. R. Hoffman (Eds.), Memory and learning: The Ebbinghaus Centennial Conference (pp.349-379). Hillsdale, NJ, US: Lawrence Erlbaum Associates, Inc.

Roediger, H. L., \& McDermott, K. B. (1993). Implicit-memory in normal human subjects. In H. Spinnler and F. Boller (Eds.), Handbook of neuropsychology, Vol. 8 (pp. 63-131). Amsterdam: Elsevier.

Schacter, D. L. (1989). Memory. In M. I. Posner (Ed.), Foundations of cognitive science (pp. 683-725). Cambridge, MA, US: The MIT Press.

Schnuerch, R., Kreitz, C., Gibbons, H., \& Memmert, D. (2016). Not quite so blind: Semantic processing despite inattentional blindness. Journal of Experimental Psychology:Human Perception and Performance, 42(4), 459-463. http://dx.doi.org/10.1037/xhp0000205

Simons, D. J. (2000). Attentional capture and inattentional blindness. Trends in Cognitive Sciences, 4(4), 147-155. http://dx.doi.org/10.1016/S1364-6613(00)01455-8

Simons, D. J., \& Chabris, C. F. (1999). Gorillas in our midst: Sustained inattentional blindness for dynamic events. Perception, 28(9), 1059-1074. http://dx.doi.org/10.1068/p2952

Sligte, I. G., Wokke, M. E., Tesselaar, J. P., Scholte, H. S., \& Lamme, V. A. F. (2011). Magnetic stimulation of the dorsolateral prefrontal cortex dissociates fragile visual short-term memory from visual working memory. Neuropsychologia, 49(6), 1578-1588.

http://dx.doi.org/10.1016/j.neuropsychologia.2010.12.010

Snodgrass, J. G., \& Vanderwart, M. (1980). A standardized set of 260 pictures: norms for name agreement, image agreement, familiarity, and visual complexity. Journal of Experimental Psychology:Human Learning and Memory, 6(2), 174.

Wood, K., \& Simons, D. J. (2019). Processing without noticing in inattentional blindness: A replication of Moore and Egeth (1997) and Mack and Rock (1998). Attention,Perception, \& Psychophysics, 81(1), $1-11$. 